\title{
Reproductive and physiological traits of Egyptian Suffolk rams as affected by selenium dietary supplementation and housing heat radiation effects during winter of the sub-tropical environment of Egypt (Short Communication)
}

\author{
IBRAHIM FAYEZ MAHMOUD MARAI', ABEL-HALIM ALI EL-DARAWANY ${ }^{1}$, EL-SAYED \\ ABOU-FANDOUD ISMAIL ${ }^{2}$ and MOHAMED AHMED MOHAMED ABDEL-HAFEZ ${ }^{2}$
}

'Department of Animal Production, Faculty of Agriculture, Zagazig University, Zagazig, Egypt, ${ }^{2}$ Department of Sheep and Goats, Institute of Animal Research, Ministry of Agriculture, Dokki, Egypt

\section{Abstract}

The present investigation was a part of a research project that aimed to study the reproductive and physiological traits of the rams as affected by selenium dietary supplementation and, housing heat radiation effect which is the change in animals perception of warmth between the different parts of the building or between indoors and outdoors of the farm measured by the difference in temperature-humidity index (THI) values.

To carry out such work, the animals were divided into four groups (A, B, C and E) of nearly equal average body weights and were raised in one shed, but divided to southern and northern parts. Two groups ( $A$ and B) were housed in the southern part of the farm (facing the bright sun day light), while the other two groups ( $C$ and $D$ ) were housed in the northern part of the farm (facing the cold air flow). One group in each part of the farm was kept without treatment as control (A or $C$ ) and the second (B or D) was treated with selenium $(0.1 \mathrm{ppm} / \mathrm{kg}$ dry matter [DM] of ration as sodium salenate) orally.

The results showed that dietary selenium supplementation improved significantly $(P<0.01$ or 0.05$)$ most of the ram traits, during winter. Regarding the housing heat radiation effect, the results showed that the southern part was higher than the northern part of the farm with $0.8 \mathrm{THI}$ unit and such change improved significantly $(P<0.01$ or 0.05$)$ the ram traits, during winter. With regard to the interaction between the studied two factors, there were no significant effects except for the scrotal circumference and scrotal length which were high $(P<0.01)$ in the rams supplemented with selenium and raised in the southern part of the farm, under the sub-tropical environment of Egypt.

Keywords: Egyptian suffolk rams, housing heat radiation effect, physiological reactions, reproductive traits, selenium supplementation

\section{Zusammenfassung}

Reproduktions- und physiologische Merkmale bei Suffolk Böcken unter dem Einfluss einer Seleniumzufütterung und höherer Temperaturen während des Winters unter subtropischen Bedingungen Ägyptens (Kurzmitteilung) 
Vorliegende Untersuchung ist Teil eines Forschungsprojektes mit dem Ziel, den Einfluss einer Seleniumzufütterung und höherer Temperaturen auf Reproduktions- und physiologische Merkmale bei Schafböcken bei unterschiedlichen Haltungsbedingungen zu untersuchen. Insgesamt 16 Suffolkböcke wurden vier Versuchsgruppen zugeordnet. Jeweils zwei Gruppen wurden in wärmeren südlichen und zwei Gruppen in kälteren nördlichen Standorten gehalten. Jeweils eine dieser Gruppen in den unterschiedlichen Sandorten erhielt Seleniumzufütterung $(0,1 \mathrm{ppm} / \mathrm{kg}$ Trockenmasse [DM] sodium selenat). Die Ergebnisse zeigten eine signifikante Verbesserung der meisten untersuchten Merkmale im Winter. Bezüglich des Wärmeeffektes d.h. eines höheren TemperaturFeuchtigkeits-Indexes (THI) bei den südlichen Gruppen verbesserten sich signifikant die untersuchten Merkmale im Winter. Im Zusammenhang mit den beiden untersuchten Einflussgrößen ergaben sich keine signifikanten Zusammenhänge zwischen dem Hodenumfang und der Hodenlänge welche bei den Seleniumgruppen in der Südregion unter subtropischen Bedingungen höhere Werte erreichten.

Schlüsselwörter: Ägypten, Suffolkböcke, Wärmeeffekt, physiologische Merkmale, Reproduktionsmerkmale, Seleniumzufütterung

\section{Introduction}

Recently, it happened in a farm that the conception rate reached $19 \%$ in a Statal flock of Egyptian Suffolk (1/16 Ossimi.15/16 U.K. Suffolk). When discussing that problem, it was observed that the rams were raised in buildings built of bricks and cement which might cause increase in animals perception of warmth (housing heat radiation effect or housing effect), under the hot sub-tropical conditions. In addition, the animals showed symptoms of selenium deficiency, although the animals were fed according to NRC (1985) requirements. The housing heat radiation effect is the change in animals perception of warmth between the different parts of the building or between indoors and outdoors of the farm, measured by the difference in temperature-humidity index (THI) values.

In this respect, a project of research was planned to investigate the reproductive traits of rams and ewes, as affected by such unfavourable conditions and the methods of its alleviation. Most of the results of the planned project of research were published (MARAI et al. 2004, 2006a, 2006b, on ewe traits and MARAl et al. 2003, 2006c on ram traits).

The objectives of the present work were to study the reproductive and physiological traits of Egyptian Suffolk rams as affected by selenium dietary supplementation and housing heat radiation effect during winter season, under Egyptian sub-tropical conditions.

\section{Material and methods}

The present study was conducted in the Department of Animal Production, Faculty of Agriculture, Zagazig University, Zagazig, Egypt. The experimental work was carried out at El-Gemmaiza Experimental Station located in mid Nile Delta $\left(30.5^{\circ} \mathrm{N}\right)$ and the laboratory work was conducted in the Department of Sheep and Goats Research, both belonging to Animal Production Research Institute, Ministry of Agriculture, Egypt. The present 
investigation was a part of a project of study on the reproductive traits of sheep as affected by the unfavourable sub-tropical conditions of Egypt.

A total number of 16 rams of Egyptian Suffolk sheep of 1.5-2.5 years of age and $60-70 \mathrm{~kg}$ body weight raised in a 3 lambings/ 2 years system were used in the present study, during December-February (winter season). The animals were divided into four groups ( $, B, C$ and $E$ ) of nearly equal average body weights and were raised in one shed, but divided to southern and northern parts. Two groups ( $A$ and $B$ ) were housed in the southern part of the farm (facing the bright sun day light), while the other two groups ( $C$ and $D)$ were housed in the northern part of the farm (facing the cold air flow). One group in each part of the farm was kept without treatment as control (A or $C$ ) and the second (B or D) was treated with selenium ( $0.1 \mathrm{ppm} / \mathrm{kg} \mathrm{DM}$ as sodium salenate) orally.

All animals were healthy and clinically free of external and internal parasites and were kept, maintained and treated in adherence to accepted standards for the humane treatment of animals.

Requirements of selenium were 0.1 to $0.2 \mathrm{ppm} / \mathrm{kg}$ DM (NRC 1985). In the experimental diet, selenium was determined on DM basis as $0.09 \mathrm{ppm} / \mathrm{kg} \mathrm{DM}$, which was nearly similar to the requirements for sheep according to NRC (1985).

The animals were offered their nutritional requirements according to NRC (1985). Additional diet was offered to rams, 15 days before and after beginning of the breeding season (35 days). The additional diet was composed of $1.0 \mathrm{~kg}$ concentrates, $0.25 \mathrm{~kg}$ barely and ad lib rice straw. Each $\mathrm{kg}$ of the concentrate contained: $450 \mathrm{~g}$ yellow maize, $350 \mathrm{~g}$ decorticated cottonseed meal, $150 \mathrm{~g}$ wheat bran, $3 \mathrm{~g}$ mollases, $1 \mathrm{~g}$ calcium carbonate and $1 \mathrm{~g}$ salt. Proximate analysis of the concentrates and roughages (Table 1) was carried out according to AOAC (1980). The animals had access to water daily three times in winter at $9.00,13.00$ and $18.00 \mathrm{~h}$.

Table 1

Chemical analyses of the diets used in experimental trails

Chemische Analyse der eingesetzten Futtermittel

\begin{tabular}{lccccccccc}
\hline Items & $\mathrm{DM}, \%$ & $\mathrm{CP}, \%$ & $\mathrm{CF}, \%$ & $\mathrm{EE}, \%$ & $\mathrm{NFE}, \%$ & $\mathrm{OM}, \%$ & $\mathrm{Ash}, \%$ & $\mathrm{Se}, \%$ & $\mathrm{Car}, \%$ \\
\hline Concentrates & 90.46 & 18.50 & 13.46 & 4.85 & 53.69 & 90.50 & 9.50 & 0.095 & 1.46 \\
Barely & 90.00 & 7.78 & 10.00 & 2.23 & 76.56 & 96.57 & 5.34 & 0.097 & 2.00 \\
Rice straw & 92.30 & 3.47 & 35.10 & 1.41 & 39.65 & 79.63 & 20.37 & 0.084 & 2.00 \\
\hline
\end{tabular}

DM dry matter, CP crude protein, CF crude fibre EE either extract, NFE nitrogen free extract, OM organic matter, Se Selenium, Car Carotene

Rams were housed in soil floored, semi-open i.e. partially wooden roofed parts. The partial roofs were in the northern side of the southern part and in the southern side in the northern part. The height of the north wall of the southern part which is the south wall of the northern part of the farm was $2 \mathrm{~m}$. Either the southern or the northern parts of the farm were divided into two partitions, each of $3 \times 8 \mathrm{~m}$ and surrounded by walls of $2 \mathrm{~m}$ height. All the walls were constructed by bricks and cement.

The methods used in the study were the same as those described by MARAl et al. (2003).

Ambient air temperature and relative humidity ( $\mathrm{RH} \%$ ) were recorded (Table 2 ) in the sheds at the times of carrying out the physiological and scrotal measurements and 
semen collection. Ambient air temperature was recorded using Mercury thermometer to the nearest $0.1{ }^{\circ} \mathrm{C}$. Maximum and minimum temperatures were recorded using thermometer. Relative humidity was recorded using hair-hygrometer to the nearest $1 \%$.

THI was estimated (Table 2) according to the following equation (MARAl et al. 2000):

$$
T H I=d b^{\circ} \mathrm{C}-\left\{(0.31-0.31 R H)\left(d b^{\circ} \mathrm{C}-14.4\right)\right\}
$$

where is $d b^{\circ} \mathrm{C}$ the dry bulb temperature in Celsius and $\mathrm{RH}=\mathrm{RH} \% / 100$. Then the obtained values of THI were classified as follows: $<22.2=$ absence of heat stress, $22.2-<23.3=$ moderate heat stress, $23.3-<25.6=$ severe heat stress and $\geq 25.6=$ very severe heat stress (MARAl et al. 2000).

Table 2

Microclimatic data during the whole experimental period

Mikroklimadaten während der Versuchsperiode

\begin{tabular}{|c|c|c|c|c|c|c|c|c|c|}
\hline & \multicolumn{4}{|c|}{ South of the farm } & \multicolumn{4}{|c|}{ North of the farm } & \multirow[b]{2}{*}{$\mathrm{DLL}, \mathrm{h}$} \\
\hline & $\begin{array}{l}\text { Air temp } \\
\text { min }\end{array}$ & $\begin{array}{l}\text { ture, }{ }^{\circ} \mathrm{C} \\
\max \end{array}$ & $\mathrm{RH}, \%$ & THI, max & $\begin{array}{l}\text { Air tem } \\
\text { min }\end{array}$ & $\begin{array}{l}\text { ature, }{ }^{\circ} \mathrm{C} \\
\max \end{array}$ & $\mathrm{RH}, \%$ & THI, max & \\
\hline $\begin{array}{l}\text { December-February } \\
\text { (Winter) }\end{array}$ & 10.0 & 20.1 & 78.4 & 19.7 & 9.2 & 18.8 & 80.5 & 18.9 & 10.5 \\
\hline
\end{tabular}

DLL day light length

Statistically, the model used to study effects of housing heat radiation (THI of the parts of the building; north and south), treatment with selenium and their interaction on semen traits, physiological parameters, scrotal measurements and blood components in rams, was as follows:

$$
Y_{i j k}=\mu+s_{i}+t_{j}+s t_{k}+e_{i j k}
$$

where is $\mu$ the overall mean, $s_{i}$ the effect due housing part ( $i=$ north and south), $t_{j}$ the fixed effect of $j$-th treatment $(j=1$ and 2$)$, $s t_{k}$ the interaction between housing part and treatment and $e_{i j k}$ the unexplained variation assumed to be randomly and independently distributed. The statistical analysis was computed using analysis of variance procedure described in SAS (1995).

\section{Results and discussion}

Physiological parameters, libido, semen characteristics and scrotal measurements as affected by dietary selenium supplementation

Tables 3 and 4 show that dietary selenium supplementation improved significantly $(P<0.01$ or 0.05$)$ libido, semen ejaculate volume, sperm motility percentage, sperm-cell concentration $\left(\times 10^{9} / \mathrm{ml}\right)$ and scrotal circumference, and deceased significantly $(P<0.01)$ percentages of dead spermatozoa, sperm abnormalities and acrosomal damage. The plasma creatinine was lower significantly $(P<0.05)$ in rams fed diet containing selenium than in those fed a diet without selenium. The other traits were insignificantly affected with the same treatment. 
Table 3

Least square means $( \pm S E)$ of physiological parameters, libido, semen characteristics and scrotal measurements in Egyptian Suffolk rams as affected by selenium treatment and housing heat radiation, during winter season Mittelwerte der physiologischen, Hoden- und Spermamerkmale bei unterschiedlichen Versuchsgruppen

\begin{tabular}{|c|c|c|c|c|c|c|}
\hline \multirow{2}{*}{ Variables } & \multicolumn{2}{|c|}{ Selenium } & \multicolumn{4}{|c|}{ Housing effect } \\
\hline & Without $(A+C)$ & With $(B+D)$ & & South $(A+B)$ & North $(C+D)$ & \\
\hline \multicolumn{7}{|l|}{ Physiological parameters } \\
\hline Rectal temperature, ${ }^{\circ} \mathrm{C}$ & $38.44 \pm 0.07$ & $38.33 \pm 0.07$ & ns & $38.70^{\mathrm{a}} \pm 0.07$ & $38.07^{b} \pm 0.07$ & ** \\
\hline Skin temperature, ${ }^{\circ} \mathrm{C}$ & $36.47 \pm 0.13$ & $36.52 \pm 0.13$ & ns & $36.68 \pm 0.13$ & $36.32 \pm 0.13$ & ns \\
\hline Scrotal skin temperature, ${ }^{\circ} \mathrm{C}$ & $27.93 \pm 0.22$ & $27.91 \pm 0.22$ & ns & $28.19 \pm 0.22$ & $27.65 \pm 0.22$ & ns \\
\hline \multicolumn{7}{|l|}{ Libido and semen characteristics } \\
\hline Reaction, Libido s & $13.33^{\mathrm{a}} \pm 0.55$ & $10.50^{\mathrm{b}} \pm 0.55$ & ** & $11.10^{\mathrm{b}} \pm 0.55$ & $12.70^{\mathrm{a}} \pm 0.55$ & * \\
\hline $\mathrm{pH}$ & $6.81 \pm 0.02$ & $6.8 \pm 0.02$ & ns & $6.81 \pm 0.02$ & $6.8 \pm 0.02$ & ns \\
\hline Semen ejaculate volume, $\mathrm{ml}$ & $0.84^{b} \pm 0.04$ & $0.97^{a} \pm 0.04$ & * & $0.96 \pm 0.04$ & $0.85 \pm 0.04$ & ns \\
\hline Sperm motility, $\%$ & $71.04^{b} \pm 0.86$ & $76.88^{a} \pm 0.86$ & ** & $75.62^{\mathrm{a}} \pm 0.86$ & $72.29^{b} \pm 0.86$ & ** \\
\hline Dead spermatozoa, $\%$ & $19.83^{\mathrm{a}} \pm 0.71$ & $13.50^{b} \pm 0.71$ & $* *$ & $15.06^{b} \pm 0.71$ & $18.27^{\mathrm{a}} \pm 0.71$ & ** \\
\hline Sperm abnormalities, $\%$ & $14.69^{\mathrm{a}} \pm 0.62$ & $9.67^{b} \pm 0.63$ & $* *$ & $11.31^{b} \pm 0.63$ & $13.04^{\mathrm{a}} \pm 0.63$ & * \\
\hline Acrosomal damage, $\%$ & $10.44^{\mathrm{a}} \pm 0.54$ & $6.23^{b} \pm 0.54$ & $* *$ & $7.85 \pm 0.54$ & $8.81 \pm 0.54$ & ns \\
\hline Sperm-cell concentration, $\times 10^{9} / \mathrm{ml}$ & $1.14^{b} \pm 0.16$ & $1.75^{\mathrm{a}} \pm 0.16$ & $* *$ & $1.69^{\mathrm{a}} \pm 0.16$ & $1.20^{\mathrm{b}} \pm 0.16$ & * \\
\hline \multicolumn{7}{|l|}{ Scrotal measurements } \\
\hline Scrotal circumference, $\mathrm{cm}$ & $32.08^{b} \pm 0.55$ & $34.24^{\mathrm{a}} \pm 0.55$ & $* *$ & $32.74 \pm 0.55$ & $33.57 \pm 0.55$ & ns \\
\hline Scrotal length, cm & $13.00 \pm 0.28$ & $13.85 \pm 0.28$ & ns & $13.87 \pm 0.28$ & $12.93 \pm 0.28$ & ns \\
\hline Testes length, cm & $11.50 \pm 0.29$ & $10.96 \pm 0.29$ & ns & $12.04^{a} \pm 0.29$ & $10.41^{b} \pm 0.29$ & ** \\
\hline
\end{tabular}

group $A / B$ without/ with selenium in southern part of the farm, group C/D without/ with selenium in northern part of the farm, means bearing different letters within the same row, differ significantly $(P<0.05),{ }^{* *} P<0.01$, ${ }^{*} P<0.05$, ns not significant

The above results were in agreement with those obtained by UNDERWOOD (1977), DYASHENKO and KATROSHENCO (1990), UDALA et al. (1995), SCOTT et al. (1998), KOLODZTEJ and JACYNO (2005) and BALICKA-RAMISZ et al. (2006). Improvement of semen quality is due to its improvement of testes function (UNDERWOOD 1977). Selenium affects the interstitial cells of testes directly and via the effect on the anterior pituitary hormones secretion indirectly (YOUSEF et al. 1990).

The increase in scrotal circumference in rams supplemented with selenium may be due to the beneficial effect of selenium on the interstitial cells of testes and protection of testes cells from damage. These results agreed with those reported by YOUSEF et al. (1990) and BURTIS and ASHWOOD (1996). SARLOS et al. (1996) and POTI et al. (1999) found a seasonal effect in scrotal circumference in which the testicular volume showed a minimum in winter.

\section{Blood components as affected by dietary selenium supplementation}

Table 4 shows that the plasma creatinine was lower significantly $(P<0.05)$ in rams dietary supplemented with selenium than in those fed a diet without selenium. The decrease in plasma creatinine in rams with selenium may be due to improvement of protein anabolism, decrease of protein catabolism, and decrease in the glucorticoid hormones such as cortisol and increase in T3 hormone. BALICKA-RAMISZ et al. (2006) reported similar results.

Generally, selenium is considered an essential nutrient for animals. It is implied in the functions of the body, connected with immunity (LARSEN 1993) and protects the animal 
from the white muscle disease (PEHRSON 1993). It is also implied in metabolism of thyroid hormones and other functions (BEHNE et al. 1990). Biochemically, selenium acts as a component of the enzyme glutathion peroxidase activity, an enzyme that catalyzes the degradation of organic hydroperoxidase. Its absence is correlated with a loss of glutathion peroxidase (GSH-Px) activity and is associated with damage to cell membranes. Cell membrane damage and normal cells are replaced with fibroblast. This condition which is known with damage to cell membranes is due to accumulation of free radicals (BURTIS and ASHWOOD 1996). Deficiency of selenium declines fertility of livestock (SANDERS 1984). BUCK et al. (1981) reported that selenium deficiency may lead to reproductive dysfunctions such as retained placenta and reduced fertility in ewes. SANDERS (1984) added that diseases due to selenium inadequacy in livestock are of a worldwide distribution.

Table 4

Least square means $( \pm \mathrm{SE})$ of blood components in Egyptian Suffolk rams, as affected by selenium treatment and housing heat radiation, during winter season

Mittelwerte der Blutkomponenten bei unterschiedlichen Versuchsgruppen

\begin{tabular}{|c|c|c|c|c|c|}
\hline \multirow{2}{*}{ Variables } & \multicolumn{2}{|c|}{ Selenium } & \multicolumn{3}{|c|}{ Housing effect } \\
\hline & Without $(A+C)$ & With $(B+D)$ & South $(A+B)$ & North $(C+D)$ & \\
\hline Total proteins, g/dl & $7.87 \pm 0.31$ & $8.11 \pm 0.31 \mathrm{~ns}$ & $8.24 \pm 0.31$ & $7.74 \pm 0.31$ & $\overline{n s}$ \\
\hline Albumin, $\mathrm{g} / \mathrm{dl}$ & $4.20 \pm 0.20$ & $4.30 \pm 0.20 \mathrm{~ns}$ & $4.53 \pm 0.2$ & $3.97 \pm 0.2$ & ns \\
\hline Globulin, g/dl & $3.67 \pm 0.13$ & $3.81 \pm 0.13 \mathrm{~ns}$ & $3.71 \pm 0.13$ & $3.77 \pm 0.13$ & ns \\
\hline Createnine, mg/L & $23.98^{\mathrm{a}} \pm 0.91$ & $20.81^{b} \pm 0.91 *$ & $21.53 \pm 0.91$ & $27.26 \pm 0.91$ & ns \\
\hline Glucose, $\mathrm{mg} / \mathrm{dl}$ & $13.72 \pm 1.86$ & $14.67 \pm 1.86 \mathrm{~ns}$ & $11.31^{\mathrm{b}} \pm 1.86$ & $17.08^{\mathrm{a}} \pm 1.86$ & * \\
\hline Alkaline phosphatase, U/L & $1294.16 \pm 10.98$ & $317.30 \pm 10.98 \mathrm{~ns}$ & $1314.04 \pm 11.00$ & $1297.44 \pm 10.98$ & ns \\
\hline $\begin{array}{l}\text { Lactate dehydrogenase, } \\
\mathrm{U} / \mathrm{L}\end{array}$ & $612.30 \pm 44.10$ & $743.86 \pm 44.1 \mathrm{~ns}$ & $751.79^{\mathrm{a}} \pm 44.10$ & $604.37^{b} \pm 44.1$ & * \\
\hline SGOT, U/L & $87.67 \pm 4.62$ & $86.00 \pm 4.63 \mathrm{~ns}$ & $92.17 \pm 4.62$ & $81.50 \pm 4.62$ & ns \\
\hline SGPT, U/L & $26.00 \pm 3.79$ & $22.33 \pm 3.79 \mathrm{~ns}$ & $21.50 \pm 3.79$ & $26.83 \pm 3.79$ & ns \\
\hline $\begin{array}{l}\text { Inorganic phosphorus, } \\
\mathrm{ng} / \mathrm{dl}\end{array}$ & $9.69 \pm 2.13$ & $7.83 \pm 2.13 \mathrm{~ns}$ & $9.34 \pm 2.13$ & $8.17 \pm 2.13$ & ns \\
\hline Zinc, $\mu \mathrm{g} / \mathrm{dl}$ & $327.35 \pm 58.67$ & $354.52 \pm 58.67 \mathrm{~ns}$ & $290.79 \pm 58.67$ & $0 \pm 58.67$ & ns \\
\hline erone, $\mathrm{ng} / \mathrm{dl}$ & $3.96 \pm 0.54$ & $7.41 \pm 0.54 \mathrm{~ns}$ & $6.77 \pm 1.55$ & $4.59 \pm 1.55$ & ns \\
\hline Estradiol, $\mathrm{Pg} / \mathrm{dl}$ & $15.51 \pm 3.57$ & $20.48 \pm 3.57 \mathrm{~ns}$ & $19.32 \pm 3.57$ & $16.67 \pm 3.57$ & ns \\
\hline $\mathrm{T} 3, \mathrm{ng} / \mathrm{dl}$ & $121.06 \pm 12.86$ & $126.20 \pm 12.86 \mathrm{~ns}$ & $94.17^{b} \pm 12.86$ & $153.10^{\mathrm{a}} \pm 12.9$ & ** \\
\hline Cortisol, $\mu \mathrm{g} / 100 \mathrm{ml}$ & $2.44 \pm \quad 0.73$ & $1.55 \pm 0.70 \mathrm{~ns}$ & $0.95 \pm 0.73$ & $3.04 \pm 0.73$ & ns \\
\hline
\end{tabular}

group A/B without/with selenium in southern part of the farm, group C/D without/ with selenium in northern part of the farm, means bearing different letters within the same row, differ significantly $(P<0.05),{ }^{* *} P<0.01$, ${ }^{*} P<0.05$, ns not significant

\section{Physiological parameters, libido, semen characteristics and scrotal measurements as affected by housing heat radiation}

Tables 3 and 4 show that the rectal temperature, libido, sperm motility percentage, sperm cell concentration $\left(\times 10^{9} / \mathrm{ml}\right)$ and testes length, percentages of dead spermatozoa and sperm abnormalities were improved significantly $(P<0.01$ or 0.05$)$ in the rams kept in the southern than in those kept in the northern part of the farm during winter season. Rectal temperature was significantly $(P<0.01)$ affected by housing heat radiation.

The housing heat radiation effect is the change in perception of warmth between the different parts of the farm or between indoors and outdoors measured in THI values. 
The estimated THI values were 19.7 and 18.9 in the south and north parts, respectively, of the farm, indicating that THI values were higher with $0.8 \mathrm{THI}$ unit in the southern than in the northern part of the farm. Length of daylight was $10.5 \mathrm{~h}$ (Table 2).

The significant increase in testes length in rams kept in the southern than in those kept in the northern part of the farm, may be due to suitability of the ambient temperature more in the southern $\left(20.1^{\circ} \mathrm{C}\right)$ than in the northern $\left(18.8^{\circ} \mathrm{C}\right)$ part of the farm, during winter.

\section{Blood components}

Table 4 shows that plasma glucose and T3 hormone were higher significantly $(P<0.01$ or $0.05)$, while LDH activity was lower significantly $(P<0.05)$ in rams kept in northern than in those kept in southern part of the farm. The increase in glucose and T3 hormone levels and decrease in LDH activity may be due to the decrease in THI in the northern than in the southern part of the farm. These results were similar to those obtained in T3 by YOUSEF and JOHNSON (1985) and MARAl et al. (1997b) and in LDH by SHAFFER et al. (1981) and SALEM et al. (1998) and in glucose by HABEEB et al. (1992) .

\section{The interaction effect}

There were no significant interaction effects, except for the scrotal circumference and scrotal length which were high $(P<0.01)$ in the rams supplemented with selenium and raised in the southern part of the farm. Such results confirmed that the southern part (with more 0.8 unit) is more suitable for the animals than the more cold northern part of the farm, during winter. This phenomenon was translated to that the scrotal circumference and the scrotal length were significantly higher in rams supplemented with selenium in the southern (facing the bright sun day light) than in the northern part of the farm (facing the cold air flow), during winter.

\section{Conclusions}

Selenium dietary supplementation (with $0.1 \mathrm{ppm} / \mathrm{kg} \mathrm{DM}$ as sodium salenate) improved most of the ram traits, during winter. The southern part of the building (facing the bright sun day light) increased with $0.8 \mathrm{THI}$ unit than the northern part of the building (facing the cold air flow), and such change improved the ram traits, during winter, under the subtropical environment of Egypt.

\section{References}

AOAC (Association of Official Agriculture Chemists) (1980) Official Methods of Analysis Washington DC

Balicka-Ramisz A, Pilarczyk B, Ramisz A, Wiecorek M (2006) Effects of selenium administration on blood serum Se content and on selected reproductive characteristics of sheep. Arch Tierz 49, 176-80

Behne D, Kyriakopulos A, Meinhold H, Kohrle J (1990) Identification of type 1 iodotheronine-5 diloinase as selenoenzyme. Biochem Biophysiol Research Commun 173, 1143-9

Buck GL, Schmitz JA, Swanson LV (1980) Incorporation of ${ }^{75}$ Se into endocrine glands and reproductive tissues of the prepartum ewe and fetus. Spallholz JE, Martin JL, Ganther HE (eds) Selenium in Biology and Medicine. Avi Publication Company Westport CT, 514

Burtis CA, Ashwood ER (1996) Tietz Fundamentals of Clinical Chemistry. Saunders, 4th ed vol 1 and 2

Dyashenko LS, Katroshenco Al (1990) The reproductive function of rams fed biotic doses of selenium and vitamin E. Sel'skokhozyaistvennaya Biologia 4, 85-8 [in Russian]

Habeeb AA, Marai IFM, Kamal TH (1992) Heat stress. In: Phillips C, Piggens D (eds) Farm Animals and the Environment, CAB International 27-47 
Kolodztiej A, Jacyno E (2005) Effect of selenium and vitamin $E$ supplementation on reproductive performance of young boars. Arch Tierz 48, 68-75

Larsen HJS (1993) Relations between selenium and immunity. Norwegian J Agric Sci 11, 105-19

Marai IFM, Abou-Fandoud El, El-Darawany AA, Fadiel A, Abdel-Hafez MA (2006a) Marker gene alleles associated with Egyptian Suffolk ewe traits. Proc 1st Int Conf on Small Rumin Prod, Cairo, Egypt, 1-6

Marai IFM, Bahgat LB, Shalaby TH, Abdel-Hafez MA (2000) Fattening performance, some behavioural traits and physiological reactions of male lambs fed concentrates mixture alone with or without natural clay under hot summer of Egypt. Ann Arid Zone 39, 449-60

Marai IFM, El-Darawany AA, Abou-Fandoud EM, Abdel-Hafez MAM (2003) Alleviation of heat stressed Egyptian Suffolk rams by treatment with selenium, melatonin or prostaglandin F2a hot summer of Egypt. J Anim Vet Advances (Faisalabad Pakistan) 2, 215-20

Marai IFM, El-Darawany AA, Abou-Fandoud El, Abdel-Hafez MAM (2004) Reproductive traits and the physiological background of the seasonal variations in Egyptian Suffolk ewes under the conditions of Egypt. Ann Arid Zone 42, 1-9

Marai IFM, El-Darawany AA, Abou-Fandoud El, Abdel-Hafez MAM (2006b) Serum blood components during pre-oestrus, oestrus and pregnancy phases in Egyptian Suffolk ewes as affected by heat stress under the conditions of Egypt. Proc 1st Int Conf on Small Ruminant Prod, Cairo, Egypt, 47-62

Marai IFM, El-Darawany AA, Abou-Fandoud El, Abdel-Hafez MAM (2006c) Tunica dartos index as a parameter for measurement of adaptability of rams to subtropical conditions of Egypt. Anim Sci J (Japan) 77, 487-94

Marai IFM, Shalaby TH, Bahgat LB, Abdel-Hafez MA (1997) Fattening of lambs on concentrates mixture diet alone without roughages or with addition of natural clay under subtropical conditions of Egypt. Physiological reactions Int Conf Animal Prod \& Health, 351-60

NRC (1985) Nutrient Requirements of Sheep. 6th ed National Academy Press 2120 Constitution NY Washington DC 20418

Pehrson B (1993) Selenium in nutrition with special reference to the biopotency of organic and inorganic compounds. In: Proc of Altech's 9th Annual Symposium Altech Technical Publ Nicholasville KY

Poti P, Bedö S, Mezes M, Tözser J (1999) Estimating reproductions ability of Hungarian Merino rams. Arch Tierz 42, 459-68

Salem JA, Kobeisy MA, Zenhom M, Hayder M (1998) Effect of season and ascorbic acid supplementation on some blood constituents of suckling Chois lambs and its crosses with Ossimi sheep in Upper Egypt Assiut. J Agric Sci 29, 87-100

Sanders DE (1984) Use of selenium in problem cattle herds. Mod Vet Pract 65, 136-8

Sarlos P, Molnar A, Huszar S, Ratky J, Brüssow, K-P (1996) Seasonal changes of andrological characteristics in British milk ram. Arch Tierz 39, 265-75

SAS (1995) Statistical Analysis System. Users Guide Statistics Version 5th ed SAS Institute Inc Cary NC

Scott R, Macpherson A, Yates RWC, Hussain B, Dixon J (1998) The effect of oral selenium supplementation on human sperm motility. British J Urology $82,76-80$

Shaffer L, Roussel JD, Koonce KL (1981) Effect of age temperature season and breed on blood characteristics of dairy cattle. J Dairy Sci 64, 62-70

Udala J, Ramisz A, Drewnowski W, Lasota B, Radoch W (1995) Semen quality of bulls treated with selenium and vitamin E. Zesyty Naukowe Akademii Rolniczej w Szcecinie Zootechnika 32, 57-63

Underwood EJ (1977) Trace elements in Human and Animal Nutrition. 3rd ed New York, USA

Yousef HM, Abul-Ela A, Farag ER, Awad YL, El-Keraby FE, Hassanin HA (1990) Effect of pre-partum selenium injection on reproductive and lactational performance and post-partum hormone profile in dairy cows. In: Proceedings of 4th Scientific Congress Faculty of Veterinary Medicine Assiut University Assiut Egypt, 445-54

Yousef MK, Johnson HD (1985) Endocrine system and thermal environment. In: Yousef MK (ed) Stress Physiology in Livestock. CRC Press Inc Boca Raton Florida USA 1, 133-54

Received 16 March 2008, accepted 24 March 2009.

Corresponding author:

Prof. Dr. IBRAHIM FAYEZ MAHMOUD MARAI

email: ifmmarai@yahoo.co.uk

Department of Animal Production, Faculty of Agriculture, Zagazig University, Zagazig, Egypt 